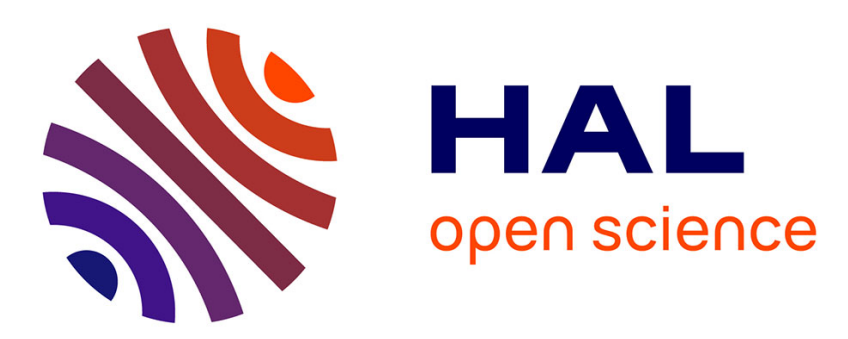

\title{
Organic farming in the vicinity of conventional arable crops: which impact on revenues and costs
}

\author{
Valentin Bellassen, Elsa Martin, Ludivine Villaverde
}

\section{To cite this version:}

Valentin Bellassen, Elsa Martin, Ludivine Villaverde. Organic farming in the vicinity of conventional arable crops: which impact on revenues and costs. International Journal of Agricultural Resources, Governance and Ecology, 2019, 15 (3), pp.195. 10.1504/IJARGE.2019.10024882 . hal-02340490

\section{HAL Id: hal-02340490 \\ https://hal.science/hal-02340490}

Submitted on 26 May 2020

HAL is a multi-disciplinary open access archive for the deposit and dissemination of scientific research documents, whether they are published or not. The documents may come from teaching and research institutions in France or abroad, or from public or private research centers.
L'archive ouverte pluridisciplinaire HAL, est destinée au dépôt et à la diffusion de documents scientifiques de niveau recherche, publiés ou non, émanant des établissements d'enseignement et de recherche français ou étrangers, des laboratoires publics ou privés. 


\title{
Organic farming in the vicinity of conventional arable crops: which impact on revenues and costs
}

\author{
Valentin Bellassen, Elsa Martin, Ludivine Villaverde
}

\begin{abstract}
Address (ADR)
Abstract: The neighbouring effect of organic fields on revenues and costs of conventional arable crop farms is tested. For this, a standard econometric model is applied to fine resolution economic and pedo-climatic data in the Deux-Sèvres département in Western France. The impact of the vicinity to organic farms on production small but significant and negative. This may either be explained by a slightly higher infestation rate or by a remnant of correlation between organic field location and poor soil quality uncontrolled for by the pedo-climatic data. In any case, a high positive impact of the vicinity to organic fields mediated by crop auxiliaries is unlikely in this region. There is no impact of the vicinity to organic farms on crop protection costs. This could be explained by a routine behaviour of conventional farmers regarding crop protection or by social interactions between organic and conventional neighbours.
\end{abstract}

Keywords: Organic farming; conventional farming; revenues; costs; neighbouring effect; vicinity; environmental externality.

Reference to this paper should be made as follows: Author(s) (2006) 'paper title ', Int. J. Ad Hoc and Ubiquitous Computing, Vol. X, No. Y4, pp.000-000.

Biographical notes: (ABS)

\section{Introduction}

There is an extensive literature on the comparison of the economic performance of organic versus conventional farms (Seufert et al. 2012; Dal Ferro et al.2017 ; Naglova and Vlasicova, 2016). Part of the difference in performance is explained by differences in farms structure and in farm characteristics. Koesling et al. (2008) show that organic farms tend to be smaller and located in areas less suited to agriculture and that organic farmers tend to be younger, better educated; they are more often women and they tend to have less farming experience and to hold more environmental values than their conventional colleagues.

To the best of our knowledge, no paper focuses on the impact of the presence of organic farming in the vicinity of conventional farms on the economy of these conventional production. This question is however an acute one. Indeed, the fear of conventional farmers that neighbouring organic fields constitutes a reserve of pests which depresses their revenues or increases their phytosanitary costs harms the image of organic farming and decreases its dissemination. To the contrary, some proponents of organic farming claim that organic fields are reservoirs of crop auxiliaries and that they therefore provide ecosystem services to their neighbours.

So far however, academics have shortcut the issue in two ways. Agricultural economists have limited their studies to the impact of crop diversity on farm productivity. This could be part of the answer as the crop rotation is more diversified in organic farms. Di Falco and Chavas (2006), based on an econometric analysis applied to farm-level data, shows that crop diversity increases agricultural yields and reduces farmers' risk exposure. More particularly, in a dynamic setting based on panel data, Di Falco and Chavas (2008) bring to the fore that crop diversity helps keeping agricultural yields constant in a climate change context. Finally, Chavas (2009) proposes a theoretical framework to measure the positive impact of biodiversity on productivity of farms. Donfouet et al. (2017) confirms the positive impact of crop diversity on farm revenues within the framework of a setting controlling for spatial dependence that could be explained by topographic, climatic and agronomic constraints. In this strand of literature, the shortcut lies in the impossibility to tell apart the landscape effect from the rotational effect (Lechenet et al., 2014). While the landscape effect is a component of the external ecosystem service - or disservice - provided by organic fields to their neighbour, the rotational effect is internal to organic farms.

Another strand of literature in ecology studies the impact of organic farming on biodiversity. Tück et al. (2014) finds that the impact, generally positive, is taxon-dependent at the agricultural plot level. Bengtsson et al. (2005) bring to the fore that this impact increases with the presence of organic farming in the landscape. Winqvist et al. (2011) adds that organic farming only improves the potential for biological control in heterogeneous landscapes. Altieri (1999) shows a positive impact of biodiversity, understood both as plant and animal biodiversity, in crop protection and soil fertility. Osgathorpe et al. (2011) brings to the fore the importance of the complementarity between species: particular species 
perform better in the presence of others. While these studies demonstrate the first part of the causal chain - organic farming increases biodiversity and, among others, the diversity and abundance of crop auxiliaries, it does not assess the second part, namely that this increase in biodiversity has a positive effect on the agricultural yield of neighbouring fields. And this second part of the causal chain cannot be taken for granted as organic fields may increase both the diversity and abundance of pests and crop auxiliaries, leaving their overall impact on neighbouring fields undetermined.

The main contribution of this paper is to look for the impact of organic farming on arable crops revenues based on both agricultural science and ecology literatures previously quoted. Here, both strands of literature are linked by analysing directly the relationship between organic farms and their neighbours' economy. To the best of our knowledge, no paper is primarily concerned with this question. Henckel et al. (2015) shows, based on data from a French region located in West (Deux-Sèvres département, equivalent to NUTS 3), that the type of biodiversity produced by organic farming can impact agricultural production in a negative way. Indeed, organic farming can increase the level of crop pests. This is why, a pesticide cost indicator for the economy of conventional production is investigated in this paper, in addition to the revenue indicator, and this is also a reason for focus on this geographic area.

Finally, a first answer to the question of the impact of organic farming on arable crops revenues and costs is proposed in this paper, based on data from a French region: Deux-Sèvres département. According to the last agricultural census (2015), 56\% of UAA (Utilized Agricultural Area) of this region is dedicated to arable crops. Furthermore, this region is characterised by the highest increase of the number of organic farms in the surroundings since 2014: $17 \%$.

The next section is dedicated to the presentation of the methodology. The results are presented in section 3 and discussed in section 4. The last section concludes.

\section{Methodology}

\subsection{Theoretical considerations}

In agricultural economics, a production function depicts the relationship between inputs and outputs. The well-known agricultural production function writes as:

\section{$\mathrm{Q}=f(v, l)$}

where $\mathrm{Q}$ is the quantity of output produced, $\mathrm{f}$ the production function depicting how inputs are combined, $\mathrm{v}$ a vector of variable inputs (fertilizers, seeds, pesticides, water, etc.) and 1 a vector of fixed inputs (land, labour, capital).
Natural capital plays a crucial role in agricultural production and inputs are adjusted by farmers in response to natural capital. Biodiversity, climate and soil are well-known natural drivers of agricultural production. The following production function is considered:

$\mathrm{Q}=f(v, l ; k)$

where $\mathrm{k}$ denotes the natural capital.

In this paper, most of the attention is paid to the impact of the natural capital $\mathrm{k}$ on the outputs produced by conventional arable crops. The impact of the natural capital induced by the vicinity of organic farms is specifically investigated: while controlling for climate and soil characteristics, the impact of biodiversity induced by the vicinity of organic farming on production is tested through different indices that will be presented in the next section. In particular, and as justified by the literature quoted in the introduction, the assumptions tested in this paper are: (i) a positive impact of the presence of auxiliaries induced by the vicinity of organic farming and (ii) a negative impact of the presence of pests induced by the same vicinity on production of arable crops.

\subsection{Data}

\subsubsection{Proxies for vicinity of organic farming}

\section{Resolution and reconstruction}

The finest information available on organic farms is their area at municipal level. The farm accountancy data that are standardized at the département level (see next section for more details on these data) were obtained at the same resolution. Consequently, the area of organic farm within the municipality is used as a proxy for the vicinity of organic farming. French municipalities are rather small: there are 305 municipalities in the Deux-Sèvres département and their average size is 2,000 ha. This resolution is reasonable for an attempt to capture a neighbouring effect of organic farming at landscape scale.

For legal reasons, the area of organic farms is masked when the number of farms at a given resolution is higher than zero and lower than three: this is the case for $30 \%$ of DeuxSèvres municipalities and $22 \%$ of the Deux-Sèvres cantons (intermediary administrative boundary between municipality and département). A simple algorithm is therefore designed to approximate the area of organic farms in masked municipalities. This algorithm respects an additivity constraint: the area at a higher administrative levels equals the sum of its constituents at lower administrative levels (Appendix 1).

\section{Four proxies for the vicinity of organic farming}

The ratio of organic arable crops fields over municipal arable crop area - hereafter index $x_{A C}$ - is chosen as the main 
Elapsed time on arrival: a simple and versatile primitive for canonical time synchronisation services 241

proxy for the vicinity of organic farming. Indeed, there is little to no application of pesticides on grassland so that their organic status is unlikely to impact crop auxiliaries or pests. However, to test the robustness of the results to both this rationale and the reconstruction algorithm for masked organic areas, three other proxies are also used:

$\checkmark$ the ratio of total organic land over total UAA including grasslands, hereafter index ${ }_{O L}$;

$\checkmark$ the ratio of number of organic farms over total number of farms, hereafter index NOF $_{\text {; }}$

$\checkmark$ the ratio of all farmland receiving little to no pesticides - organic crops, grasslands and fallows over total UAA, hereafter index ${ }_{L P}$.

Municipal data on area per crop type are obtained from Registre Parcellaire Graphique (RPG, 2014). Total UAA at département level is very close and slightly larger than the older but reputedly more exhaustive agricultural census (Agreste, 2010). The number of farms at municipal level is obtained from the 2010 agricultural census (Agreste, 2010). The descriptive statistics of these proxies show that the share of organic farming is limited to an average $1.5 \%$ and never exceeds $22 \%$ (Table 1). Furthermore, most of these proxies are not distributed in a Gaussian way, especially Index $_{\mathrm{AC}}$ on which the results section is focused (Figure 1). Figure 2 provides a spatial representation of Index $\mathrm{AC}_{\mathrm{C}}$.

Table 1. Descriptive statistics of the proxies for the vicinity of organic farming

\section{Figure 1. Number of municipalities per class of index $x_{A C}$ (expressed in \%)}

\section{Figure 2. Location of sample farms and distribution of index $_{\mathrm{AC}}$ in the Deux-Sèvres département}

\subsubsection{Accountancy data}

The dependant variables - revenues and costs - and most of the independent variables - land (UAA), labour quantity, and the costs of other inputs (fertilizers, pesticides, seeds, machinery, ...) - were obtained from the accounting books of the farms for the year 2014 and the Deux-Sèvres département and compiled by the regional farm accountancy association, Cerfrance Poitou-Charentes (See Table 2 for descriptive statistics). Only farms specialized in arable crops are included, and the sample does not include any organic farms according to Cerfrance Poitou-Charentes. To make sure of this latter point, the two farms which recorded no costs for plant protection were removed from the sample, resulting in 278 farms located within a circle of $60 \mathrm{~km}$ radius. It is important to note that the sample is not exhaustive since farmers can choose an independent bookkeeper. However, in France and more particularly in Deux-Sèvres Département, most of conventional arable crop farmers chooses Cerfrance as their bookkeeper. ${ }^{1}$

\subsubsection{Other data sources}

To limit endogeneity, namely through the correlation of the vicinity of organic farming with omitted variables driving revenues or cost, pedo-climatic conditions at municipal level are controlled for, using very detailed and fine resolution independent variables (see Table 2 for descriptive statistics). The 1981-2010 average growing season (March to August) temperature and the 1981-2010 average water stress season (February to June) precipitation are derived from Météo-France (2013). Fifteen soil variables obtained at a 1/250 000 resolutions - totalling 253 soil mapping units over the Deux-Sèvres département - were obtained from the Chambre régionale d'Agriculture (Donesol, 2006) and rescaled at municipal level to make them comparable with other data. For one of the robustness checks, the available water content (awc) is also computed using the Rawls equation (UVED, 2011).

\section{Table 2. Descriptive statistics of accountancy and} other data

\subsection{Empirical models}

Based on data previously presented, the main aim is to test the impact of organic farming in the vicinity of conventional arable crops on the revenues and costs of these conventional productions. For this purpose, two main models are used, a revenue and cost one, in which the previous indices for organic farming presence in the vicinity of arable crop farms are introduced.

For the revenue model, the model is based on a CobbDouglas production function (Ibrahim and Alam, 2016) that

\footnotetext{
${ }^{1}$ The alternative accountancy data available are the one from the FADN (Farm Accountancy Data Network) which are not publicly available under NUTS 2 level. To give an idea of the statistical validity of the sample with respect to these data, it contains 278 arable crop farms located in a single département (equivalent to NUTS 3 ) whereas the FADN dataset contains around 8000 farms for the whole France among which 2000 are specialized in arable crops; on average, a département contains only around 20 FADN farms specialized in crops.
} 
describes the crop agricultural production as a non-linear combination of agricultural inputs: fixed inputs (land, labour, capital) and variable inputs (seeds, fertilizer, pesticides...). The data provided are accountancy data and most of them are expressed in euros. The output is approximated with the revenues of the farm; capital is approximated with mechanization costs and variables inputs with variables costs. Assuming that prices are the same for all farmers, the Cobb-Douglas specification remains valid. Different versions of the indices of the presence of organic farming are tested.

Finally, the revenue model is as follows:

$$
\begin{aligned}
\ln \left(\text { revenues }_{i}\right)= & \beta_{0}+\beta_{1} \ln \left(\text { land }_{i}\right)+\beta_{2} \text { labour }_{i}+\beta_{3} \ln (\text { varia } \\
& +\beta_{6} \text { control }_{i}+\varepsilon_{i}
\end{aligned}
$$

Because of the assumption of a possible negative impact of organic farming on arable crops revenues, through the possible development of crop pests, a cost model is also tested. Here, pesticides costs are explain by other variables costs (seeds and fertilizers) to capture complementarity and substitutability effects between them. Pesticides costs are also explained by revenues and fixed costs (sum of land, labour and mechanization costs) and non linearity is assumed through the introduction of logarithms. Some control variables are also tested for the same reason as before and organic farming indices.

Finally, the cost model is as follows:

\section{$\ln$ (pesticide costs)}

$=\beta_{0}+\beta_{1} \ln \left(\right.$ revenues $\left._{i}\right)+\beta_{2} \ln ($ fixed costs $+\beta_{5}$ index $_{i}+\beta_{6}$ control $_{i}+\varepsilon_{i}$

\section{Results}

\subsection{Small or non-existing externality on production}

In the baseline model derived from the classical CobbDouglas production function, all four main inputs - land, labour, operational costs and mechanization costs - have a positive and significant impact on revenues, as expected (Table 3). A large share of total variance is explained by the model $\left(r^{2}>0.9\right)$ which highlights the importance of these key inputs in explaining farm revenues, as has been found in other studies (Ibrahim and Alam, 2016). The land elasticity is surprisingly small - 0.35 - but comparable to other similar studies (Argiles and Brown, 2011). Furthermore, when it is summed up with the elasticities of variable and mechanization costs, the cumulated elasticity of these major production factors is close to unity as expected in this type of model (Ibrahim and Alam, 2016).

\section{Table 3. Effect of vicinity to organic farms on revenues}

p-value: . $<0.1 ; *<0.05 ; * *<0.01 ; * * *<0.001$.

The effect of the vicinity to organic farms is found to be either negative (index $\mathrm{x}_{\mathrm{AC}}$ and index $\mathrm{x}_{\mathrm{OL}}$ ) or null (index $\mathrm{N}_{\mathrm{NOF}}$ and index $x_{L P}$ ), depending to the proxy chosen for organic vicinity. Even in the models where the vicinity to organic farms is found to decrease revenues of conventional farmers, the effect size is small: given the observed variability in index $\mathrm{AC}_{\mathrm{C}}$ in the sample (Table 1), the conventional average farm would undergo a modest $0.9 \%$ decrease in revenues if the share of organic fields in its municipality was to increase from the first quartile $00 \%-$ to the third quartile $-1.7 \%$ - observed.

If anything, this result favours the hypothesis of higher pest levels in organic field contaminating the neighbouring conventional fields rather than the hypothesis of a positive externality from neighbouring organic fields mediated by more crop auxiliaries at landscape levels. The decreasing effect of the vicinity to organic farms with the decreasing specificity of the index supports this interpretation: pests tend to be crop-specific so a higher density of organic crops in the neighbourhood - index $\mathrm{AC}_{\mathrm{C}}$ - has a more negative effect than a higher density of organic area land - index $\mathrm{OL}_{\mathrm{L}}$ - or a higher density of untreated land - index $x_{L P}$.

This analysis is not immune to endogeneity though, and in particular omitted variable bias: organic farms have been shown to be preferentially located in areas with poorer

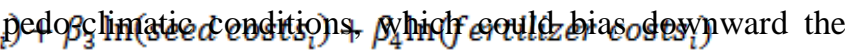
estimator. Given that pedo-climatic conditions are largely controlled for by fine resolution information, this bias is unlikely to be strong. And given that we did not find any instrument suited to the dataset, we believe that the evidence is strong enough to support the conclusion that vicinity to organic fields has a small and negative or inexistent impact on conventional farm revenues.

\subsection{No externality on pesticide costs}

Turning to the test of hypothesis according to which higher pest levels in organic fields contaminate the neighbouring conventional fields, a pesticide costs model is run. This hypothesis is supported by the previous result according to which organic farming in the vicinity of conventional arable crops have a negative impact on the revenues of these latter one.

In the baseline model, revenues and fertilizer costs have a positive and significant impact on pesticide costs (Table 4). The positive elasticity of pesticide demand with respect to crop prices is a classical result (Williams and Shumway, 2000). The cross price elasticity of pesticide demand with 
Elapsed time on arrival: a simple and versatile primitive for canonical time synchronisation services 243

respect to fertilizer price is less documented because of data availability reasons. However, the positive impact of fertilizer costs on pesticide costs can be explained by a wellestablished phenomenon in agronomy according to which an increase of fertilizer use increases the risk of pest infestation (Rossing et al., 1997) and, as a consequence, the amount of pesticides applied. Also, fixed costs (sum of land, labour and mechanization costs) have a negative impact on pesticide costs (Table 4). Here, the interpretation relies on substitutability between pesticide applications and other methods aiming at reducing the level of pest infestations which relies on fixed input factors such as labour (Pardo et al., 2010). Table 4 also shows that seed costs have no significant effects on pesticide cost which is not surprising. The baseline model explains a satisfactory share of total variance $\left(r^{2}>0.70\right)$.

When indices summing up the vicinity of organic farming are introduced, the baseline model remains robust. The absence of significant effect for all indices introduced show that there is no externality on pesticide costs. Consequently, the assumption of higher pesticide use in the vicinity of organic fields is rejected. In other words, conventional farmers apply the same amount of pesticides whatever the presence of organic farming in their vicinity.

\section{Table 4. Effect of vicinity to organic farms on pesticide costs}

\section{Conclusion and extensions}

The main aim of this study was to look for the impact of the presence of organic farms in the vicinity of conventional farms on the economy of these latter. The effect on revenues is found to be small or non-existing. When small, the effect is negative. Such a negative effect can be explained by the fact that higher pest levels in organic fields contaminate the neighbouring conventional fields. However, when looking at the impact of the presence of organic farms in the vicinity of conventional farms on pesticide costs, there is no evidence of a significant impact.

To interpret this apparent paradox, the literature on technology adoption in agriculture is useful since it shows the influence of human capital and social network on farmers' choices (Bandiera and Rasul, 2006; Foster and Rosenzweig, 1995). The small negative impact of the presence of organic farms in the vicinity of conventional farms on their revenues, combined with the absence of impact on pesticide costs, could be explained by the social impact that organic farmers play on conventional one. More particularly, the presence of organic farms can induce an imitation effect or a modification of the yields to be achieved by conventional farms. An alternative explanation could be a routine behaviour of conventional farmers with regards pesticides: farmers may follow a relatively homogeneous technical advice on the amount of pesticides to be applied, notwithstanding the vicinity of organic fields and the possibly related slightly higher level of infestation.

These conclusions do not weaken the rationale for subsidizing organic farming for its impact on water quality (Benoit et al., 2014) or other environmental externalities (Muller et al., 2017). However, they do not offer any ground to support an increase in subsidies for the improvement of the "food production" ecosystem service at landscape scale. On the other hand, the conclusions largely contradict the negative perception that some conventional farmers have of the vicinity of organic fields.

To confirm these results, two main extensions could be considered. First, it would be interesting to extend the analysis to other regions or countries and to other agricultural productions. For data availability reasons, the analysis was conducted on arable crops of Deux-Sèvres Département, France. Consequently, the results are valid for arable crops of this region. There is no obvious specificity in this Département which would undermine the validity of these results in other areas with the similar production conditions. However, it would be interesting to test them in other agricultural contexts where conventional and organic agriculture coexist. A second possible extension could consist in extending the analysis at the plot level whereas ours is conducted at the aggregated municipal level. Parker et al. (2007) show that neighbourhood is an important driver of the location of organic fields at the plot level. Based on such a plot level analysis, it could be interesting to see if the small negative effect on revenues and the absence of impact on pesticide costs would remain valid. Such extensions would be easily implementable if economic data at the plot scale and for other study area and agricultural production were available.

Finally, another interesting extension would be to test the impact of the presence of conventional farms in the vicinity of organic farms on the economy of these latter. Such an extension would be implementable if sufficient economic data of organic farms were available.

\section{Appendix 1. Algorithm to approximate masked areas}

Data on the areas of organic fields distinguishes the following crop types: forage crops, fruits, field crops, vegetables, aromatic and medicinal plants, vines and other crops. An additional category sums all categories: data may be unmasked for this "ALL" category and masked for more 
specific categories. At the département level, the data are unmasked for all crop types.

At the canton level, 78 out of 297 canton x crop type data are masked. Their value is approximated in a two-step procedure:

1) A first proxy is based on the number of organic farms in the canton (Equation 1).

\section{Equation 1}

$\overline{\mathbf{U A A} \_\mathbf{O F}}_{\mathrm{c}, \mathbf{i}}=\left(U A A_{-} O F_{d, i}-\sum_{\text {unmasked cantons }} U A A_{-} O F_{c, i}\right) \times \frac{N_{c, i}}{N_{d, i}}$ Benoit,

Where $\overline{\text { UAA_OF }}_{\mathbf{c} \mathbf{i}}$ is the utilized arable area under organic farming in canton c for crop type i, UAA_OF $\mathrm{d}_{\mathrm{d}, \mathrm{i}}$ is the utilized arable area under organic farming in the département $\mathrm{d}$ to which the canton $\mathrm{c}$ belongs, $\mathrm{N}_{\mathrm{c}, \mathrm{i}}$ is the number of organic farms in canton $\mathrm{c}$ and $\mathrm{N}_{\mathrm{d}, \mathrm{i}}$ is the number of organic farms in the département $\mathrm{d}$ to which the canton $\mathrm{c}$ belongs.

2) Where the organic area for some crop types is masked but where the organic area for ALL crop types is available, the first proxy is refined in a second step to ensure that the sum of all available and approximated UAA_OF equals the data for type ALL at canton level (Equation 2).

\section{Equation 2}

UAA_OF $\mathbf{F}_{\mathbf{c}, \mathbf{i}}={\overline{\mathbf{U A A} \_0 F_{\mathbf{c}, \mathbf{i}}}} \times \frac{U A A \_O F_{c, A L L}}{\sum_{i /[A L L]} U A A \_O F_{c, i}}$

At the municipal level, 376 out of 2745 canton x crop type data are masked. 187 out of 305 municipalities in the département do not contain any organic field. The above algorithm is repeated at municipal level, replacing canton with municipality and département with canton.

\section{References}

Agreste, 2010. Recensement général agricole (RGA) [online database]. https://stats.agriculture.gouv.fr/cartostat/\#v= map2;i=stru1.saumoy10;I=fr (Accessed 1 March 2017)

Altieri, M.A., 1999. The ecological role of biodiversity in agroecosystems. Agriculture, Ecosystems \& Environment 74, 19-31.

Argiles, J.M., Brown, N.D., 2011. A comparison of the economic and environmental performances of conventional and organic farming: evidence from financial statements. Agricultural Economics Review 11 (1), 69-86.

Bandiera, O., Rasul, I., 2006. Social Networks and Technology Adoption in Northern Mozambique. The Economic Journal 116, 869-902.

Bengtsson, J., AhnströM, J., Weibull, A.-C., 2005. The effects of organic agriculture on biodiversity and abundance: a meta-analysis: Organic agriculture, biodiversity and abundance. Journal of Applied Ecology 42, 261-269.

Nitrate leaching from organic and conventional arable crop farms in the Seine Basin (France). Nutrient Cycling in Agroecosystems 100, 285-299.

Chavas, J.-P., 2009. On the Productive Value of Biodiversity. Environmental Resource Economics 42, 109-131.

Dal Ferro, N., Zanin, G., Borin, M., 2017. Crop yield and energy use in organic and conventional farming: A case study in north-east Italy. European Journal of Agronomy 86, 37-47.

Di Falco, S., Chavas, J.-P., 2008. Rainfall Shocks, Resilience, and the Effects of Crop Biodiversity on Agroecosystem Productivity. Land Economics 84, 83-96.

Di Falco, S., Chavas, J.-P., 2006. Crop genetic diversity, farm productivity and the management of environmental risk in rainfed agriculture. European Review of Agricultural Economics 33, 289-314.

Donesol, 2006. Base de données Donesol [soil database] [C INRA, Unité INFOSOL, Orléans, Agrosup Dijon, 1998, 2006, 2005.

Donfouet, H.P.P., Barczak, A., Détang-Dessendre, C., Maigné, E., 2017. Crop Production and Crop Diversity in France: A Spatial Analysis. Ecological Economics 134, 29-39.

Foster, A.D., Rosenzweig, M.R., 1995. Learning by Doing and Learning from Others: Human Capital and Technical Change in Agriculture. Journal of Political Economy 103, 1176-1209.

Guyomard H. (eds), 2013. Vers des agricultures à hautes performances. Volume 1 . Analyse des performances de l'agriculture biologique. INRA, Paris (France).

Henckel, L., Borger, L., Meiss, H., Gaba, S., Bretagnolle, V., 2015. Organic fields sustain weed metacommunity dynamics in farmland landscapes. Proceedings of the Royal Society 
Elapsed time on arrival: a simple and versatile primitive for canonical time synchronisation services 245

B: Biological Sciences 282, 2015000220150002.

Ibrahim, A.Z., Alam, M.M., 2016. Climatic changes, government interventions, and paddy production: an empirical study of the Muda irrigation area in Malaysia. International Journal of Agricultural Resources, Governance and Ecology 12, 292-304.

Koesling, M., Flaten, O., Lien, G., 2008. Factors influencing the conversion to organic farming in Norway. International Journal of Agricultural Resources, Governance and Ecology 7, 78-95.

Lechenet, M., Bretagnolle, V., Bockstaller, C., Boissinot, F., Petit, M.-S., Petit, S., MunierJolain, N.M., 2014. Reconciling Pesticide Reduction with Economic and Environmental Sustainability in Arable Farming. PLoS ONE 9, e97922.

Météo-France, 2013. [meteorological database] Source Météo-France, traitements ODR, version 12/2010. INRA, Toulouse, France.

Muller, A., Schader, C., El-Hage Scialabba, N., Brüggemann, J., Isensee, A., Erb, K.-H., Smith, P., Klocke, P., Leiber, F., Stolze, M., Niggli, U., 2017. Strategies for feeding the world more sustainably with organic agriculture. Nature Communications 8, 1290.

Naglova, Z., Vlasicova, E., 2016. Economic Performance of Conventional, Organic, and Biodynamic Farms. Journal of Agriculture Siences and Technology 18, 881-894.

Osgathorpe, L.M., Park, K., Goulson, D., Acs, S., Hanley, N., 2011. The trade-off between agriculture and biodiversity in marginal areas: Can crofting and bumblebee conservation be reconciled? Ecological Economics 70, 11621169.

Pardo, G., Riravololona, M., Munier-Jolain, N.M., 2010. Using a farming system model to evaluate cropping system prototypes: Are labour constraints and economic performances hampering the adoption of Integrated Weed Management? European Journal of Agronomy 33, 24-32.

Parker, D.C., Munroe, D.K., 2007. The geography of market failure: Edge-effect externalities and the location and production patterns of organic farming. Ecological Economics 60, 821-833.

Rossing, W., Jean-Marc, M., Ittersum, M.K., 1997. Model-based explorations to support development of sustainable farming systems: Case studies from France and the Netherlands. Developments in Crop Science 7, 339-351.

RPG, 2014. Réseau parcellaire graphique 2014 [database on agricultural plots], source Agence de services et de paiement, traitements Observatoire du développement rural. INRA, Toulouse, France.

Seufert, V., Ramankutty, N., Foley, J.A., 2012. Comparing the yields of organic and conventional agriculture. Nature 485, 229232.

Tuck, S.L., Winqvist, C., Mota, F., Ahnström, J., Turnbull, L.A., Bengtsson, J., 2014. Land-use intensity and the effects of organic farming on biodiversity: a hierarchical meta-analysis. J Appl Ecol 51, 746-755.

UVED, 2011. Estimation de la réserve utile (RU) en $\mathrm{mm}$ [website]. Université Virtuelle Environnement \& Développement Durable. http://uved.univ-lemans.fr/Grain-1_Kit_1Bilan/co/grain_Exo_02.html (accessed 1.19.18).

Williams, S.P., Shumway, C.R., 2000. Trade Liberalization and Agricultural Chemical Use: United States and Mexico. American Journal of Agricultural Economics 82, 183-199.

Winqvist, C., Bengtsson, J., Aavik, T., Berendse, F., Clement, L.W., Eggers, S., Fischer, C., Flohre, A., Geiger, F., Liira, J., Pärt, T., Thies, C., Tscharntke, T., Weisser, W.W., Bommarco, R., 2011. Mixed effects of organic farming and landscape complexity on farmland biodiversity and biological control potential across Europe. Journal of Applied Ecology 48, 570-579. 